\title{
Factors associated with pasung (physical restraint and confinement) of schizophrenia patients in Bogor regency, West Java Province, Indonesia 2017
}

Nenden Hikmah Laila ${ }^{1,2}$, Renti Mahkota ${ }^{2,3^{*}}$ (D) Siddharudha Shivalli, ${ }^{4,5}$, Krisnawati Bantas ${ }^{2}$ and Tri Krianto ${ }^{6}$

\begin{abstract}
Background: Schizophrenia is a chronic mental disorder affecting more than 21 million worldwide. In Indonesia, $14.3 \%$ of households have a patient with a mental disorder, and the majority of these are in rural areas. Family members in Indonesia use repressive social measures like pasung (physical restraint and confinement) for these patients. A study was conducted with the objective to determine the factors associated with pasung among patients with schizophrenia in Bogor Regency, West Java Province, Indonesia 2017.
\end{abstract}

Methods: A case-control study was conducted in Bogor Regency from May-June 2017. A case subject was defined as a patient with schizophrenia who was ever subjected to pasung and a control subject was defined as a patient with schizophrenia residing in the same geographical area and never subjected to pasung. Multi-stage sampling was used to select case and control subjects from the registered reports of the Health Service of Bogor Regency (2012-16) in 34 sub districts and 59 health centers. Multivariate logistic regression was used to identify the factors associated with pasung. Attributable and population attributable risks (AR, PAR) for pasung were calculated.

Results: A total of 114 case and 136 control subjects were studied. Patient's aggressive or violent behavior (AdjOR: 4.49, 95\%Cl: 2.52-8.0), unemployment (AdjOR: 2.74, 95\%Cl: 1.09-6.9) and informal employment (AdjOR: 2.5, 95\%Cl: 1. 1-5.84) in the family and negative attitude of the family towards the patient (AdjOR: 2.52, 95\%Cl: 1.43-4.43) were associated with pasung. Patient's aggressive or violent behavior (PAR $=44.3 \%)$ and unemployment in the family (PAR $=49.3 \%)$ were the predominant factors of pasung.

Conclusions: Patient's aggressive or violent behavior, negative attitude of the family towards the patient and unemployment in the family were associated with pasung. We recommend health education and encouraging family members to shift patients with schizophrenia exhibiting aggressive or violent behavior to a mental health facility. Strengthening of basic mental health services and involving family members while treating patients with schizophrenia to develop positive attitudes could be considered. Creating employment opportunities and a social support system for treated patients with schizophrenia and family members could further avert pasung.

Keywords: Schizophrenia, Pasung, Aggressive, Violent, Discourse

\footnotetext{
* Correspondence: r-mahkota@ui.ac.id

${ }^{2}$ Department of Epidemiology, Faculty of Public Health, Universitas Indonesia, Depok 16424, Indonesia

${ }^{3}$ Faculty of Public Health, Mahidol University, Bangkok 10400, Thailand

Full list of author information is available at the end of the article
}

(c) The Author(s). 2019 Open Access This article is distributed under the terms of the Creative Commons Attribution 4.0 International License (http://creativecommons.org/licenses/by/4.0/), which permits unrestricted use, distribution, and reproduction in any medium, provided you give appropriate credit to the original author(s) and the source, provide a link to the Creative Commons license, and indicate if changes were made. The Creative Commons Public Domain Dedication waiver (http://creativecommons.org/publicdomain/zero/1.0/) applies to the data made available in this article, unless otherwise stated. 


\section{Background}

Schizophrenia is a severe and chronic mental disorder affecting more than 21 million people worldwide. It is more common and appears early in men. Estimated worldwide prevalence of schizophrenia ranges from 0.51\% [1]. Schizophrenia is associated with considerable disability and may affect educational and occupational performance. Schizophrenia has multifactorial etiology and it is thought that interactions between genes, psychological and various environmental factors may lead to schizophrenia [2]. People with schizophrenia are 22.5 times more likely to die at an early age. The disorder is often caused by physical illness, such as cardiovascular, metabolic, or infectious diseases. In nearby communities, it is commonplace to see the evidence of stigma, discrimination and human rights abuses targeted at individuals with schizophrenia [2].

Some families consider a chronic mental disorder to be a heavy burden. Poor knowledge of mental disorder in the family and lack of motivation to provide care make the predicament more complex. In addition, economic burden on the family owing to loss of productivity of the affected person and high cost of care further augments the problem. It becomes worse with the social stigma and discrimination of the affected person. Stigma is a social problem in which the environment negatively labels one's situation or condition and it includes attitudes of rejection, denial, and isolation. Family members often take regressive measures on patients with mental disorder due to stigma induced stress and sense of helplessness [3-5]. Under these circumstances, it is difficult for patients to work or to enjoy a satisfactory quality of life [5].

According to article 1 of the Universal Declaration of Human Rights by the United Nations in 1948, all persons are free and have equal rights and dignity. This protects the fundamental rights of persons with physical or mental disabilities [6]. One of the regressive measures is physical restraint and confinement of the affected person and is referred to as pasung in Indonesia [3]. This is defined as isolation and restriction of space of a person with mental disorder to control the madness [7]. Deprivation of a person with mental disorder is a violation of human rights. Pasung is common in developing countries, including Indonesia. Absence of the rule of law, low level of education, limited understanding of mental disorders and economic constraints contribute to pasung [8]. In addition to use of wood or leg chains to restrict movements, pasung also involves confinement and neglect [9].

The prevalence of severe mental illness in Indonesia is $0.17 \%$ [9]. In Indonesia, $14.3 \%$ of the households have a patient with mental disorder, and a majority of these are in rural areas. In West Java Province, the prevalence of severe mental disorder is $0.16 \%$ [9]. Reports of related studies state that age and sex of the patient, patient's aggressive or violent behavior, education status of the family, economic constraints and health insurance for treatment were associated with pasung or regressive measures among patients with schizophrenia [10-13]. Worldwide, most patients with schizophrenia live in low and middle income countries where access to treatment can be difficult [2]. Such regressive measures and lack of treatment increase the risk of suicide among patients with schizophrenia $[1,14,15]$.

West Java (20\%) and DKI Jakarta (14.1\%) Provinces have the first and second highest prevalence of mental disorder in Indonesia [3]. In Bogor Regency, 1323 patients with schizophrenia were reported from 2016 to 17 , and from 2012 to 16,75 patients with schizophrenia were in pasung, mostly unreported to medical practitioners [16]. Factors associated with pasung in schizophrenia have not been studied in Bogor Regency. Identification of these factors would help to streamline the existing mental health services and prevent pasung.

\section{Objective}

To determine the factors associated with pasung of patients with schizophrenia in Bogor Regency, West Java Province, Indonesia 2017.

\section{Methods}

\section{Study design and setting}

A case-control study was conducted in Bogor Regency of West Java Province, Indonesia from May-June, 2017. Bogor is one of the 17 regencies of West Java Province, Indonesia with a total population of 5.13 million and is subdivided in 40 sub districts (Kecamatan). The public health infrastructure consists of one district hospital and 101 community health centers (Pusat Kesehatan Masyarakat; puskesmas). Puskemas is a part of the three-tier system of Indonesian public healthcare. Puskemas provide maternal and child health care, preventive, promotive, and curative healthcare services. A total of 1323 patients with schizophrenia were recorded in the report on People with Mental Disorders and registration reports of Health Service of Bogor Regency in 2016 [16].

A case was defined as a patient with schizophrenia (diagnosed by a medical doctor i.e. general practitioner or psychiatrist and recorded in the disease visit register at Bogor District Health Office), who was under or ever subjected to pasung as reported by the head of the family. In this study, pasung was defined as any form of physical restraint (tying hands with rope, use of wood or leg chains to restrict movements) and/or isolation/confinement for at least one day. A control was defined as a patient with schizophrenia but who had reportedly never experienced pasung. 


\section{Sample size and sampling}

Based on the reported 38\% prevalence of aggressive or violent behavior among patients with schizophrenia [17], and after applying continuity correction, the study required 111 case and 111 control subjects, to achieve a power of $80 \%$ to detect an anticipated odds ratio of 2.2 between case and control subjects at a two sided $p$-value of 0.05 . A center wise list of patients with schizophrenia was obtained from the report of people with mental disorder in Bogor Regency until March 2017 in 34 sub districts (total 40) and 59 health centers from 101 Puskesmas. The maximum number of subjects to be selected in each center was decided by probability proportionate to size. In each center, simple random sampling was used to select the required number of patients with schizophrenia and they were categorized as case and control according to definitions. This was continued until the required number of cases and controls was obtained.

\section{Data collection}

A semi-structured questionnaire was used to collect the relevant data from one of the family members (aged > 18 years) of the case or control subject. The following information was obtained from the interviewee: key sociodemographic characteristics of the patient with schizophrenia (age, sex, marital status and area of residence) and family (economic, education and employment status of the family member), relapse (hospitalization of patient within one year due to schizophrenia), aggressive or violent behavior (intention to cause pain, damage or destruction to another), suicidal tendency, knowledge of schizophrenia and attitude of the family towards patient and health insurance.

Based on the existing literature, two 20-item questionnaires were used to assess the knowledge of schizophrenia $[5,14,18-21]$ and attitude of the family towards the patient $[7,22,23]$. Based on the scores, knowledge of schizophrenia was categorized as good (score $\geq$ median) and poor (score $<$ median). Similarly, attitude of the family was categorized as positive (score $<$ median) and negative (score $\geq$ median).

According to monthly income of the family, economic status was categorized as high (>Indonesian Rupiah, IDR $2,500,000$ ), middle (IDR 1,500,000-2,500,000) and low (<IDR 1,500,000) [24].

\section{Data analysis}

Descriptive statistics like proportions and percentages and mean ( \pm standard deviation) were used for categorical and continuous variables, respectively. The Chi-square test was used for bivariate analysis. Variables with $p<0.25$ on bivariate analysis were considered for multivariate logistic regression analysis. Backward elimination was performed for insignificant covariates to obtain a fit model. A two-sided $p<0.05$ was considered as statistically significant. Attributable risk (AR) and population attributable risk (PAR) for pasung among patients with schizophrenia were also calculated. All statistical analysis was performed using statistical software STATA $^{\oplus}$, V12.

\section{Results}

A total of 114 case and 136 control subjects were studied. Mean $( \pm S D)$ age of the patients with schizophrenia was $32.75 \pm 9.48$ years (case: $33.04 \pm 9.40$ years and control subjects: $32.51 \pm 9.56, \mathrm{t}=-0.45 p=0.66)$. More than two thirds (66.67\%) were males and mean duration of schizophrenia was 12.76 years (range: $1-43$ years). As much as 29.5 and $21.4 \%$ of case and control subjects were married, respectively. Most patients (96.8\%) were residing in rural areas of Bogor Regency. Among case subjects, mean duration of pasung was 1.3 years (range: 1 day-12 years). Pasung was initiated by the father (27.19\%), mother (32.46\%), or elder sibling (9.65\%). Indonesian national health insurance (Jaminan Kesehatan Nasional, JKN) was administered by the BPJS Social Insurance Administration Organization (Badan Penyelenggara Jaminan Sosial, BPJS). Among the study participants, BPJS PBI (Free health insurance) was the most common type of insurance (67.26\%).

Table 1 shows key demographic and disease related characteristics of patients.

Bivariate analysis revealed patient's aggressive or violent behavior (OR: 5.19, 95\%CI: 2.89-9.35), relapse (OR: 4.37, 95\%CI: 1.18-24.09), unemployment in the family (OR: 2.4, 95\%CI: 1.04-5.53) and negative attitude of the family (OR: 3.26, 95\%CI: 1.8-5.67) were associated with pasung among patients with schizophrenia [Table 2]. On the contrary, patients with health insurance (OR: 0.51, 95\% CI: 0.25-1.00) had lower odds of pasung.

Multivariate analysis determined factors with $p<0.25$ on bivariate analysis including patient's age, patient's aggressive or violent behavior, self-mutilation/suicide attempt, relapse, family employment status, attitude of the family, health insurance, economic status and area of residence [Table 3].

In the final regression model [Table 4], patients with aggressive or violent behavior were more likely to get pasung than non-aggressive (AdjOR: 4.49, 95\%CI: 2.528.0). Based on family's employment status, patient with unemployed and informal employment family were more likely to get pasung than patients with formal employment family (AdjOR: 2.54, 95\%CI: 1.1-5.84 and AdjOR: 2.74, 95\%CI: 1.09-6.9, respectively). Patients with negative attitude family were more likely to get pasung than patients with normal attitude family (AdjOR: 2.52, 95\%CI: 1.43-4.43). 
Table 1 Demographics and health insurance of pasung case on schizophrenic sufferers $(N=250)$

\begin{tabular}{|c|c|c|}
\hline Variable & Numbers/Mean & Percentage/range \\
\hline Age mean (range) years & 32.75 years old & $15-62$ years old \\
\hline \multicolumn{3}{|l|}{ Sex } \\
\hline Male & 76 & 66.67 \\
\hline Female & 38 & 33.33 \\
\hline \multicolumn{3}{|l|}{ Education } \\
\hline Low & 101 & 88.6 \\
\hline Median & 10 & 8.77 \\
\hline High & 3 & 2.63 \\
\hline \multicolumn{3}{|l|}{ Marriage } \\
\hline Marriage & 18 & 15.79 \\
\hline Unmarried & 64 & 56.14 \\
\hline Divorced/widowed & 32 & 28.07 \\
\hline \multicolumn{3}{|l|}{ Aggressive/violent behavior } \\
\hline Yes & 69 & 60.53 \\
\hline No & 45 & 39.47 \\
\hline Duration of Illness: mean (range) & 12.76 years & $1-43$ years \\
\hline \multicolumn{3}{|l|}{ Relapse $(n=108)$} \\
\hline Yes & 105 & 97.22 \\
\hline No & 3 & 2.78 \\
\hline Duration of Pasung: mean (range) & 1.3 years & 1 day - 12 years \\
\hline \multicolumn{3}{|l|}{ Pasung initiated by } \\
\hline Father & 30 & 27.19 \\
\hline Mother & 37 & 32.46 \\
\hline Son/daughter & 8 & 7.02 \\
\hline Old brother/sisters & 11 & 9.65 \\
\hline Young brother/sister & 7 & 7.02 \\
\hline Others (big family, neighbors, shaman) & 18 & 16.67 \\
\hline \multicolumn{3}{|l|}{ Health Insurance $(n=113)$} \\
\hline BPJS PBI/Free health insurance & 76 & 67.26 \\
\hline BPJS Perusahaan/Health insurance company & 4 & 3.54 \\
\hline BPJS Mandiri/Paid health insurance & 14 & 12.39 \\
\hline No & 19 & 16.81 \\
\hline
\end{tabular}

Table 5 shows AR and PAR for pasung in the study population. Aggressive or violent behavior of the patient had the highest AR of $77.7 \%$ for pasung when compared to the other factors which had an AR in the range of 60.3 to $63.5 \%$. Unemployment in the family had the highest PAR of $49.3 \%$ for pasung when compared to negative attitude in the family and aggressive or violent behavior of the patient which had PAR of 44.3 and $34.9 \%$, respectively.

\section{Discussion}

Pasung is an age-old problem associated with patients with chronic mental disorders and has been reported worldwide [25-27]. In the study setting, pasung was associated with aggressive or violent behavior of the patient with schizophrenia, informal employment/ unemployment in the family and negative attitude of the family towards the patient. In the study population, 49.3, 44.3 , and $34.9 \%$ of the pasung among patients with schizophrenia could be averted by addressing unemployment in the family, aggressive or violent behavior of the patient, and promoting positive attitude among family members, respectively.

Patients with chronic mental disorders with aggressive behavior or violence and hallucinations are at high risk of injuring themselves, others, and the environment [5]. 
Table 2 Bivariate analysis of various factors associated with pasung of patients with schizophrenia in Bogor Regency, Indonesia 2017 $(\mathrm{N}=250)$

\begin{tabular}{|c|c|c|c|c|c|c|c|}
\hline \multirow[t]{2}{*}{ Variable } & \multicolumn{2}{|c|}{ Case $(N=114)$} & \multicolumn{2}{|c|}{ Control $(N=136)$} & \multirow{2}{*}{$\begin{array}{l}\text { Crude } \\
\text { OR }\end{array}$} & \multirow[t]{2}{*}{$95 \% \mathrm{Cl}$} & \multirow[t]{2}{*}{$p$-value } \\
\hline & $\mathrm{n}$ & $\%$ & $n$ & $\%$ & & & \\
\hline \multicolumn{8}{|l|}{ Age (years) } \\
\hline$<32$ & 53 & 46.49 & 77 & 56.62 & 0.66 & $0.39-1.13$ & $0.11^{\mathrm{a}}$ \\
\hline$>32$ & 61 & 53.51 & 59 & 43.38 & & & \\
\hline \multicolumn{8}{|l|}{ Sex } \\
\hline Male & 76 & 66.67 & 95 & 69.85 & 0.86 & $0.48-1.52$ & 0.58 \\
\hline Female & 38 & 33.33 & 41 & 30.15 & & & \\
\hline \multicolumn{8}{|l|}{ Marital status } \\
\hline Divorced/widowed & 96 & 60.5 & 107 & 79.6 & 1.35 & $0.7-2.6$ & 0.38 \\
\hline Married & 18 & 29.5 & 27 & 21.4 & & & \\
\hline \multicolumn{8}{|l|}{ Aggressive/violentbehavior } \\
\hline Yes & 69 & 60.53 & 31 & 22.79 & 5.19 & $2.89-9.35$ & $<0.001^{\mathrm{a}}$ \\
\hline No & 45 & 39.47 & 105 & 77.21 & & & \\
\hline \multicolumn{8}{|c|}{ Self mutilation/suicide attempt } \\
\hline Yes & 61 & 53.51 & 62 & 45.59 & 1.37 & $0.80-2.33$ & $0.21^{\mathrm{a}}$ \\
\hline No & 53 & 46.49 & 74 & 54.41 & & & \\
\hline \multicolumn{8}{|l|}{ Relapse } \\
\hline Yes & 105 & 97.22 & 120 & 88.89 & 4.37 & $1.18-24.09$ & $0.01^{\mathrm{a}}$ \\
\hline No & 3 & 2.78 & 15 & 11.11 & & & \\
\hline \multicolumn{8}{|l|}{ Family education } \\
\hline Low & 101 & 88.6 & 109 & 80.15 & 0.57 & $0.10-3.08$ & 0.52 \\
\hline Medium & 10 & 8.77 & 23 & 16.91 & 1.23 & $0.26-5.65$ & 0.78 \\
\hline High & 3 & 2.63 & 4 & 2.94 & & & \\
\hline \multicolumn{8}{|c|}{ Family member's employment } \\
\hline Unemployed & 69 & 60.53 & 76 & 55.88 & 2.4 & $1.04-5.53$ & $0.03^{\mathrm{a}}$ \\
\hline Informal employment & 33 & 28.95 & 32 & 23.53 & 2.11 & $0.99-4.48$ & $0.05^{\mathrm{a}}$ \\
\hline Formal employment & 12 & 10.53 & 28 & 20.59 & & & \\
\hline \multicolumn{8}{|l|}{ Family's knowledge } \\
\hline Less & 61 & 53.51 & 67 & 49.26 & 1.18 & $0.69-2.01$ & 0.5 \\
\hline Good & 53 & 46.49 & 69 & 50.74 & & & \\
\hline \multicolumn{8}{|l|}{ Family's attitude } \\
\hline Negative & 73 & 64.04 & 48 & 35.29 & 3.26 & $1.8-5.67$ & $<0.001^{\mathrm{a}}$ \\
\hline Positive & 41 & 35.96 & 88 & 64.71 & & & \\
\hline \multicolumn{8}{|l|}{ Health Insurance } \\
\hline Yes & 18 & 15.79 & 36 & 26.67 & 0.51 & $0.25-1.00$ & $0.03^{\mathrm{a}}$ \\
\hline No & 96 & 84.21 & 99 & 73.33 & & & \\
\hline \multicolumn{8}{|l|}{ Economic status } \\
\hline Low & 83 & 79.05 & 76 & 63.33 & 1 & $0.34-2.89$ & 1 \\
\hline Middle & 14 & 13.33 & 28 & 23.33 & 2.18 & $0.88-5.39$ & $0.09^{\mathrm{a}}$ \\
\hline High & 8 & 7.62 & 16 & 13.33 & & & \\
\hline \multicolumn{8}{|l|}{ Area of residence } \\
\hline Rural & 112 & 98.25 & 130 & 95.59 & 2.58 & $0.44-26.58$ & $0.23^{\mathrm{a}}$ \\
\hline Urban & 2 & 1.75 & 6 & 4.41 & & & \\
\hline
\end{tabular}

In a study from Aceh, Indonesia, aggressive behavior and dangerous action were the main reasons for pasung in schizophrenia (79.7\%). Such a behavior is often associated with feelings of anger, enmity, fear, ideas regarding murderous impulses or other psychotic processes such as hallucinations. Schizophrenia with 
Table 3 Preliminary regression model for factors associated with pasung of patients with schizophrenia in Bogor Regency, Indonesia $2017(\mathrm{~N}=250)$

\begin{tabular}{llll}
\hline Variable & OR & $95 \% \mathrm{Cl}$ & $p$-value \\
\hline Age $>$ 32 years & 0.41 & $0.21-0.80$ & 0.009 \\
Aggressive/violent behavior & 5.41 & $2.65-11.05$ & $<0.001$ \\
Self mutilation/ suicide & 0.64 & $0.32-1.26$ & 0.2 \\
Relapse & 9.03 & $1.53-53.06$ & 0.01 \\
Family employment status & & & \\
$\quad$ Unemployed & 2.94 & $0.97-8.88$ & 0.05 \\
$\quad$ Informal & 2.33 & $0.84-6.42$ & 0.1 \\
Negative attitude of the family & 2.43 & $1.27-4.65$ & 0.007 \\
No health insurance & 0.35 & $0.15-0.80$ & 0.01 \\
Economic status & & & \\
$\quad$ Low & 0.51 & $0.14-1.86$ & 0.31 \\
$\quad$ Middle & 1.14 & $0.37-3.48$ & 0.81 \\
$\quad$ Residing in rural area & 0.47 & $0.06-3.37$ & 0.45 \\
\hline
\end{tabular}

aggressive or violent behavior generally cannot be controlled [2]. In such a scenario, family members implement pasung owing to a sense of helplessness and feeling threatened by the aggressive or violent behavior of the patient [5]. In addition to aggressive or violent behavior, factors such as concern about the patient wandering off or running away, possibility of suicide and unavailability of a caregiver have been reported as the reasons of pasung in another study from Indonesia [25].

Financial hardship due to poverty or unemployment in the family or both may be the root cause of pasung. Families under financial hardship are unlikely to seek healthcare and loss of productivity further augments the problem. More than $90 \%$ of people with untreated schizophrenia live in low and middle income countries [2]. These untreated chronic patients are at high risk of aggressive or violent behavior, and even committing suicide, force the family members to implement pasung [11-13]. Creating employment opportunities for schizophrenia-treated patients and their family members with a social support system is needed. On the contrary,

Table 4 Final regression model for the factors associated with pasung of patients with schizophrenia in Bogor Regency, Indonesia $2017(\mathrm{~N}=250)$

\begin{tabular}{llll}
\hline Variable & AdjOR & $95 \% \mathrm{Cl}$ & $p$-value \\
\cline { 2 - 4 } Aggressive/violent behavior & 4.49 & $2.52-8.0$ & $<0.001$ \\
Family employment status & & & \\
$\quad$ Unemployed & 2.74 & $1.09-6.9$ & 0.03 \\
$\quad$ Informal & 2.54 & $1.1-5.84$ & 0.02 \\
Negative attitude of the family & 2.52 & $1.43-4.43$ & 0.001 \\
\hline
\end{tabular}

Pseudo $\mathrm{R}^{2}=0.1558$
Table 5 Attributable and population attributable risks for pasungof patients with schizophrenia in Bogor Regency, Indonesia 2017 ( $\mathrm{N}=250)$

\begin{tabular}{lll}
\hline Variable & AR\% & PAR\% \\
\hline Aggressive/violent behavior & 77.7 & 44.3 \\
Family employment status & & \\
$\quad$ Unemployed & 63.5 & 49.3 \\
$\quad$ Informal & 60.6 & 26.6 \\
Negative attitude of the family & 60.3 & 34.9 \\
\hline
\end{tabular}

lack of time to care for or unavailability of a caregiver could also result in pasung $[11,25]$.

According to related studies, young age of onset and being male were associated with pasung as relapse and violent behavior were more common among them, respectively $[11,12]$. In addition, lack of health insurance, lower education, and economic status of the family were also associated with pasung [11-13].

Attitudes of the family are one of the most powerful predictors of clinical relapse in schizophrenia [28]. A positive and empathic attitude, i.e., the ability to perceive the patient's mood state, was associated with reduced relapse [29]. In this study, negative attitude of the family was associated with pasung.

Medication adherence plays an essential part in decreasing the aggressive/violent episodes of a patient with schizophrenia [30]. However, it was beyond the scope of our study to directly measure treatment adherence. The following questions indicate important aspects of treatment adherence for further research of pasung in this patient population: was medication prescribed, was it the right medication at the right dose, was it monitored, did the family give it to the patient, did the patient refuse it, did the patient have adverse effects, were different medications, different doses tried? However, we did consider relapse as a proxy indicator of treatment adherence. On bivariate and preliminary regression analysis, relapse (poor adherence) was associated with pasung. Nevertheless, it was excluded from the adjusted final regression model because it did not show a statistically significant association with pasung.The existence of treatment gaps and need of scaling up of mental health services, particularly in low and middle income countries has been emphasized [31, 32]. One study in Southwest Ethiopia found that traditional healers were the first source sought for mental illness treatment. They believed that mental illnesses were caused by supernatural factors [33]. Increasing knowledge of family and community members is important to improve treatment seeking behaviors of patients with mental illness. Affordable and equitable access to basic mental health services appears to be an effective and sustainable strategy [27]. 


\section{Limitations}

Inherent limitations of a case-control study such as selection and recall bias would be applicable to this study. Selection bias could occur when eligible subjects were not willing to participate. In this study, one schizophrenia patient died before being interviewed. To minimize selection bias, we selected cases and controls from Bogor District Health Office reported from 2012 to 2016 and from pasung case findings reported in 2017 following the inclusion and exclusion criteria. Recall bias could have occurred because of the subjectivity of the enumerator. Therefore, to overcome this information bias, we trained the enumerators.

\section{Conclusion}

Unemployment in the family, patient's aggressive or violent behaviour and negative attitude of the family towards the patient were associated with pasung. Another recommendation is to encourage families to permit patients exhibiting violent behavior to be treated in a mental health facility for appropriate treatment. Health education of family members and community is recommended to create awareness and develop positive and empathetic attitude towards patients with schizophrenia. Strengthening of basic mental health services and involving family members while treating patients with schizophrenia (by clarifying misconceptions of schizophrenia, explaining the negative impact of pasung on patient, importance of medication adherence, training for home-based care, etc.) to develop positive attitudes could be considered. In addition, creating employment opportunities and a social support system for treated patients with schizophrenia and family members could further avert pasung.

\section{Abbreviations \\ AdjOR: Adjusted Odds ratio; AR: Attributable risk; \\ BPJS: Badan Penyelenggara Jaminan Sosial (Social Insurance Administration Organization); Cl: Confidence interval; IDR: Indonesian Rupiah; JKN: Jaminan Kesehatan Nasional (Indonesian national health insurance); OR: Odds ratio; PAR: Population attributable risk; \\ Puskesmas: Pusat Kesehatan Masyarakat (community health center); \\ SD: Standard deviation}

\section{Acknowledgements \\ The authors would like to thank the District Health Office and Community Health Centers in Bogor Regency for their cooperation while conducting research. The authors would also like to acknowledge Mr. Thomas McManamon, Mahidol University, Thailand for language editing and proofreading.}

\section{Funding}

This publication was supported by a grant from the Centers for Disease Control and Prevention (CDC) through TEPHINET, a program of the Task Force for Global Health, Inc. and Ministry of Health, Indonesia. Its contents are solely the responsibility of the authors and do not necessarily represent the views of The Task Force for Global Health, Inc. TEPHINET, CDC or the Ministry of Health, Indonesia. The funder had no role in the design of the study and collection, analysis, and interpretation of data and in writing the manuscript.

\section{Availability of data and materials}

The datasets used and/or analysed during the current study are available from the corresponding author on reasonable request.

\section{Authors' contributions}

$\mathrm{NHL}, \mathrm{RM}, \mathrm{TK}$, and $\mathrm{KB}$ were involved in conceptualizing and designing the study. NHL, RM, and SS searched literature. NHL, RM, and TK prepared the questionnaire and collected the data. $\mathrm{NHL}, \mathrm{SS}$, and RM analyzed the data and prepared the manuscript. TK and KB reviewed the manuscript. All authors read and approved the final manuscript.

\section{Ethics approval and consent to participate}

Ethics approval was obtained from the Ethics Commissions of Research and Community Service, Faculty of Public Health, University of Indonesia, Jakarta, Indonesia (364/UN2.F10/PPM.00.02/2017). Written informed consent was obtained from a family member (aged $>18$ years) as a respondent of the patient with schizophrenia for voluntary participation. No patient was interviewed (and hence no consent from patient). In addition, the study also aimed to assess the association of family level factors (knowledge and attitude of family members) with pasung. The study followed the tenets of the Declaration of Helsinki.

\section{Consent for publication}

Not applicable.

\section{Competing interests}

The authors declare that they have no competing interests.

\section{Publisher's Note}

Springer Nature remains neutral with regard to jurisdictional claims in published maps and institutional affiliations.

\section{Author details}

'Lebak Distric Health Office, Rangkasbitung, Lebak, Tangerang, Banten 42311, Indonesia. ${ }^{2}$ Department of Epidemiology, Faculty of Public Health, Universitas Indonesia, Depok 16424, Indonesia. ${ }^{3}$ Faculty of Public Health, Mahidol University, Bangkok 10400, Thailand. ${ }^{4}$ Non-Communicable Disease Regional Technical Advisor, Southeast Asia Regional Office (SEARO), TEPHINET, A Program of the Task Force for Global Health, Inc., Decatur, GA 30030, USA. ${ }^{5}$ Department of Medical Statistics, London School of Hygiene and Tropical Medicine, London, UK. ${ }^{6}$ Department of Health Education and Behavioral Sciences, Faculty of Public Health, Universitas Indonesia, Depok 16424, Indonesia.

Received: 22 January 2018 Accepted: 2 May 2019

Published online: 28 May 2019

\section{References}

1. Andreasen N, Black D. Introductory textbook of psychiatry. 4th ed. Washington, DC: American Psychiatric Publishing, Inc; 2006.

2. WHO. Schizophrenia [Internet]. Who.int. 2018 [cited 15 October 2018] Available from: http://www.who.int/en/news-room/fact-sheets/detail/ schizophrenia.

3. Humas FIK. Terapi Untuk Keluarga Terbukti Turunkan Keputusan Pasung. UI Update. 2014 [Cited 15 Oct 2018]. Available from: http://uiupdate.ui.ac.id/ content/terapi-untuk-keluarga-terbukti-turunkan-keputusan-pasung.

4. Humas FIK. Memutus Rantai Tindakan Pasung di Masyarakat | Ulupdate [Internet]. UI Update.2016 [cited 15 Oct 2018]. Available from: http:// uiupdate.ui.ac.id/article/memutus-rantai-tindakan-pasung-di-masyarakat.

5. Daulima N. Proses pengambilan keputusan tindakan pasung oleh keluarga terhadap klien gangguan jiwa. Depok: Universitas. Indonesia. Disertation; 2014.

6. United Nations General Assembly. A/RES/46/119. The protection of persons with mental illness and the improvement of mental health care [Internet]. United Nations. 1991 [cited 2018 Oct 15]. Available from: https://www.un. org/documents/ga/res/46/a46r119.htm

7. Wirya A. Rezim Kebenaran Rasionalisme dalam Diskursus Kegilaan dan Tindakan Pendisiplinan Pasung sebagai Kejahatan. J Kriminologi Indones. 2017;9(2):1-19.

8. Firdaus F. Pemenuhan Hak Atas Kesehatan Bagi Penyandang Skizofrenia di Daerah Istimewa Yogyakarta (rights fulfillment on health of people with 
Schizophrenia in special region of Yogyakarta). J IIm Kebijak Huk. 2016;10(1): 87-103.

9. Kemenkes RI. Riset Kesehatan Dasar; RISKESDAS. Jakarta: Badan Penelitian dan Pengembangan Kesehatan, Kementerian Kesehatan Rl; 2013.

10. Dewi R, Marchira C. Riwayat Gangguan Jiwa pada Keluarga dengan Kekambuhan Pasien Skizofrenia di RSUP Dr Sardjito Yogyakarta. Ber Kedokt Masy. 2012;25(4):176.

11. Sari H. Pengaruh Family Psychoeducation Therapy Terhadap Beban dan Kemampuan Keluarga Dalam Merawat Klien Pasung di Kabupaten Bireun. Depok: Universitas Indonesia; 2009.

12. Puteh I, Marthoenis M, Minas $\mathrm{H}$. Aceh free Pasung: releasing the mentally ill from physical restraint. Int J Ment Heal Syst. 2011;5:10.

13. Idaiani $S$, Raflizar R. FAKTOR YANG PALING DOMINAN TERHADAP PEMASUNGAN ORANG DENGAN GANGGUAN JIWA DI INDONESIA (factors contributing to shackling practice of psychotic people in Indonesia). Bul Penelit Sist Kesehat. 2015;18(1):11-17.

14. Long W. Schizophrenia: a hand book for family. Health Canada: Ottawa; 1997

15. Lopez-Morinigo J-D, Ayesa-Arriola R, Torres-Romano B, Fernandes AC, Shetty $\mathrm{H}$, Broadbent $\mathrm{M}$, et al. Risk assessment and suicide by patients with schizophrenia in secondary mental healthcare: a case-control study. BMJ Open. 2016;6(9):e011929.

16. P2P (Penanggulangan Penyakit Menular). Laporan Orang dengan Gangguan Jiwa. Bogor: Dinas Kesehatan Kabupaten Bogor; 2017.

17. Coid JW, Ullrich S, Kallis C, Keers R, Barker D, Cowden F, et al. The relationship between delusions and violence. JAMA Psychiatry. 2013;70(5): 465-71.

18. Depkes. Petunjuk Teknis Asuhan Keperawatan Pasien Gangguan Skizofrenia. Jakarta: Direktorat Jenderal Palayanan Medik; 1989.

19. Amir N, Kusumawardhani A, Husain A, Adikusumo A, Damping C. Buku Ajar Psikiatri. Jakarta: Fakultas Kedokteran Universitas Indonesia; 2010

20. Skizofrenia LS. Jakarta: Fakultas Kedokteran Universitas Indonesia; 2007

21. Mansjoer A. Kapita selekta kedokteran. Media Aesculapius. 2000.

22. Notoatmodjo S. Pendidikan dan perilaku kesehatan. Jakarta: Rineka Cipta; 2003

23. Friedman M. Keperawatan Keluarga: Teori dan Praktik. Translated by: Debora, I. Jakarta: Penerbit Buku Kedokteran EGC; 1995.

24. Kartono K. Pemimpin dan Kepemimpinan: Apakah Kepemimpinan Abnormal Itu? Jakarta: PT. Rajagrafindo Persada; 2006.

25. Minas H, Diatri H. Pasung: physical restraint and confinement of the mentally ill in the community. Int J Ment Heal Syst. 2008;2(1):8.

26. Malik S, Bokharey I, Malik SB, Bokharey IZ. Breaking the chains. Psychiatr Bull. 2001;25:273-5.

27. Krosnar K. Mentally ill patients in Central Europe being kept in padlocked, caged beds. BMJ. 2003;327(7426):1249

28. Kavanagh DJ. Recent developments in expressed emotion and schizophrenia. Br J Psychiatry. 1992;160:601-20

29. Girón M, Gómez-Beneyto M. Relationship between empathic family attitude and relapse in schizophrenia: a 2-year followup prospective study. Schizophr Bull. 1998;24(4):619-27.

30. Varghese; A, G G. Treatment approaches in aggressive behavior : an overview. EC Psychol psychiatry 2, vol. 6; 2017. p. 228-36.

31. Eaton J, McCay L, Semrau M, Chatterjee S, Baingana F, Araya R, et al. Scale up of services for mental health in low-income and middle-income countries. Lancet. 2011;378(9802):1592-603.

32. The Guardian. "Living in hell": mentally ill people in Indonesia chained and confined | global development | the Guardian [internet]: The Guardian; 2016. Available from: https:/www.theguardian.com/global-development/ 2016/mar/21/living-in-hell-indonesia-mentally-ill-people-chained-confinedhuman-rights-watch-report. [cited 15 Oct 2018]

33. Girma E, Tesfaye M. Patterns of treatment seeking behavior for mental illnesses in Southwest Ethiopia: a hospital based study. BMC Psychiatry. 2011;11(1):138

Ready to submit your research? Choose BMC and benefit from:

- fast, convenient online submission

- thorough peer review by experienced researchers in your field

- rapid publication on acceptance

- support for research data, including large and complex data types

- gold Open Access which fosters wider collaboration and increased citations

- maximum visibility for your research: over $100 \mathrm{M}$ website views per year

At $\mathrm{BMC}$, research is always in progress.

Learn more biomedcentral.com/submissions 